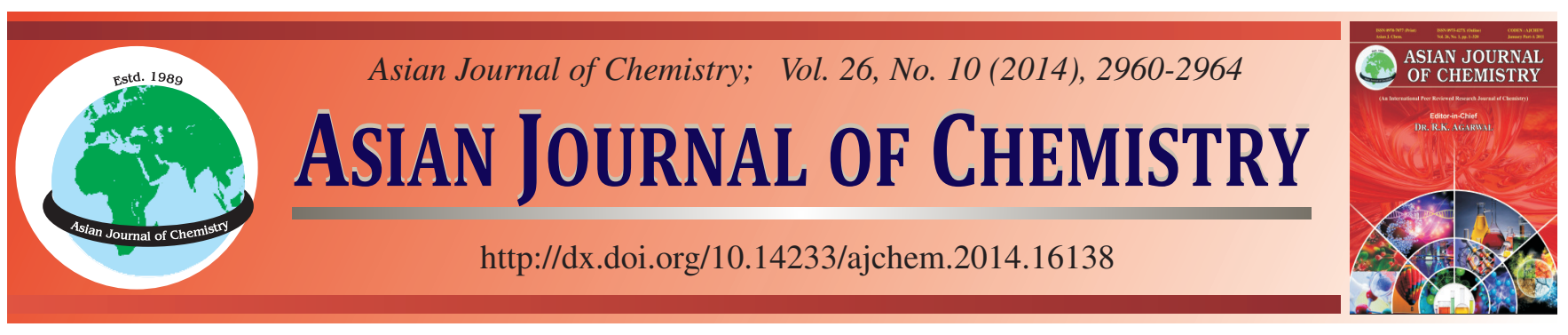

\title{
Phytochemical, Antibacterial and Antifungal Activities of Alkaloids Extracted from Peganum harmala (Linn.) Seeds of South of Algeria
}

\author{
N. Behidj-Benyounes*, T. Dahmene, N. Allouche and A. Laddad
}

Laboratory of Soft Technologies, Valorisation, Physico-chemistry of Biological Material and Biodiversity, Faculty of Sciences, University M'Hamed Bougara of Boumerdès, Boumerdès 35000 Algeria

*Corresponding author: Tel: +213 772 595094; E-mail: behidj_nassima@yahoo.fr

\begin{abstract}
This work reports the phytochemical screening of the plant extracts recovered from the seeds of Peganum harmala L. (Zygophyllaceae). Preliminary phytochemical analysis of plants extracts showed the presence of alkaloids, coumarins, saponins, quinones and flavonoids free. These natural substances are recovered by different solvents (aqueous, ethanolic and hexane). Thus evaluation of the antimicrobial activity has only touched the alkaloids. The antimicrobial effect of alkaloids is evaluated on several microorganisms. It should be noted that these agents are characterized by a high frequency of contamination and pathogenicity. It is noted that Staphylococcus aureus, Saccharomyces cerievisae and E. coli are very sensitive in respect of the ethanol extract. Pseudomonas aerogenosa and Penicillium sp. are resistant to this extract. The other microorganisms are moderately sensitive. The study of the antimicrobial activity of different extracts of the seeds of Peganum harmala L. showed an optimal activity with the ethanol extract.
\end{abstract}

Keywords: Peganum harmala, Seeds, Alkaloids, Antimicrobial activity.

\section{INTRODUCTION}

According to Roland ${ }^{1}$, the World Health Organization estimates that around $80 \%$ of world inhabitants have recourse to traditional preparations based on plants as first health care. After a long period of empiricism, herbal medicine has entered in a rational phase with an analysis of the active principles. So, in anticancer treatments, many medicines used in chemotherapy contain only plant molecules.

According to Lhuillier ${ }^{2}$ that nowadays around $75 \%$ of African population has recourse to medicinal plants and don't have access to medicines called modern. Delaveau ${ }^{3}$ confirms that this traditional pharmacopoeia discovered by the first explorers of Africa was introduced in many medicines in Europe. According to Catier and Roux ${ }^{4}$, empiricism is no longer used. It was possible to isolate, identify and analyze all the plants used in therapeutics. The active substances contained in these plants and the properties which express their use are also studied.

In Algeria, most patients use medicinal plants as an alternative remedy to treat various types of illness including urolithiasis. In this regard, six medicinal plants are selected from eleven listed by the ethnopharmacological investigation to studying there inhibiting effect on calcium oxalate lithiasis. Cynodon dactylon L, Quercus prinus L and Punica granatum $\mathrm{L}$ represent the most popular plant used by local population ${ }^{5}$.
In this country, plants occupy a very important place in the traditional medicine. Remedies using plants are low cost, without undesirable effects tend to be used in many chronicle diseases ${ }^{5}$. Although reports have been published in the literature on the antimicrobial activity of alkaloids of P. harmala ${ }^{6}$.

In this framework, we were particularly interested in Harmel plant (P. harmala L) from the family of Zygophyllaceae. Medicinal properties of Harmel are due to the presence of many alkaloids; the most important are Harmin and Harmalin. El-Dwairi ${ }^{7}$ notes that $P$. harmala extracts's have an effect of on female Albino rats fertility and pregnancy.

The aim of this work is to study the antimicrobial effect of the fruits of $P$. harmala $\mathrm{L}$. The material used during this work is resumed in a biological material containing the plant which is the fruits of Harmel, the microorganisms and a nonbiological material.

\section{EXPERIMENTAL}

About the biological material we have used a vegetable material (plant) and microbial stumps.

In the plant, the used part is the aerial one, precisely the fruits which are rich in natural substances ${ }^{8}$.

$P$. harmala L. fruits were harvested in the region of Boussaada (M'Sila). The capsule was harvested between the 
end of spring and the beginning of summer (May) after fruits maturation. The recovered aerial parts are dried in a dry and airy place store in dark for many weeks.

The antimicrobial effect of alkaloids of P. harmala L. seeds is evaluated on many microorganisms. It was tested on eight bacterial stains: Staphylococcus aureus, Pseudomonas aerogenosa, Klebseilla pneumonia, Bacillus subtilis, Klebseilla ornitthinolytica, Steptococcus faecalis, Escherichia coli and Entrococcus faecium. It was studied on two kind of yeasts: Candida albicans and Saccharomyces cerievieae. Finally three mouldes which are Aspergillus niger, Fusarium oxysporum and the Penicillium sp. It's noteworthy that these agents are characterized by an important frequency of contamination and phatogynicity.

Extraction of plant substances from $P$. harmala seeds: The adopted method during this work is by Soxhlet extraction suggested by Leger ${ }^{9}$. It permits to obtain excellent results and has a remarkable reputation when it is applied on plant field. This extraction is done using different solvents which are water, ethanol and hexane.

The antimicrobial activity of alkaloids recovered from $P$. harmala L. seeds is determined by the method of diffusion in an agar environment cited by Sacchetti et al. ${ }^{10}$ and Celiktas et al. ${ }^{11}$. The first step is the preparation of microbial stumps. It is followed by an antibiogram. This method has the advantage to be very flexible in choosing the tested antibiotics, to be applied to big number of bacterial species and to be largely evaluated during 50 years of world usage ${ }^{12}$.

\section{RESULTS AND DISCUSSION}

Phytochemical analysis of $\boldsymbol{P}$. harmala plant extracts: The phytochemical screening has firstly permitted to be informed about the chemical family of the components of El Harmel seeds. This process has facilitated the choice of the bioactive substances to study. The whole results of phytochemical screening done on $P$. harmala $\mathrm{L}$. seeds are summarized in Table-1.

\begin{tabular}{lcl}
\multicolumn{3}{c}{ TABLE-1 } \\
& PHYTOCHEMICAL TESTS OF P. harmala \\
\hline Metabolites & Fruits & Positive results \\
\hline Alkaloids & +++ & Precipitate red \\
Anthocyanes & - & Red \\
Coumarines & ++ & Trouble \\
Flavonoides & + & Orangey red \\
Glucosides & - & Brick red \\
Leuco nthocyanes & - & Red \\
Quinones & & Red \\
Free Quinones & ++ & Red a bit \\
Combined Quinones & - & Intense \\
Saponosides & +++ & Precipitate white \\
Catechic tannins & - & Red \\
Gallic tannins & - & Dark blue \\
\hline
\end{tabular}

According to the results, it is noticed that the principle components present in large quantities in P. harmala L. are the alkaloids followed by coumarines and saponosides. The free quinines are present in moderated quantities. Flavonoides are present in weak quantity. It is noticed that the seeds of El Harmel are without anthocyanes, glucosites, leuco anthocyanes, combined quinines and catechic tannins.
In this work, the results of phytochemical tests of $P$. harmala L. are in accordance with those of Munir et al ${ }^{13}$. These authors noted that $P$. harmala $\mathrm{L}$. is a very rich in indolic alkaloids. They confirmed that it is particularly seeds which contain more alkaloids rather than the other organs of the plant. Kartal et al. ${ }^{14}$ mention that Harmel seeds are a rich source of alkaloids from B-carboline type like harmol, harmin and har maline. According to Han et al. ${ }^{15}$, these alkaloids as well as other secondary metabolites of this plant explain the toxic effect on the devastators of plants. Other constituents like free quinons and the tannins are also present in P. harmala $\mathrm{L} .^{16}$.

According to Claude ${ }^{17}$, the seeds are usually rich in oils and in proteins which are considered as material reserves. Whereas seeds of $P$. harmala L. are an exception. The same author cites that Harmel can be classified among alkaloiferes plants.

In fact, Han et al. ${ }^{15}$ and El Allagui et al. ${ }^{18}$ showed that the profile of alkaloids of seeds and the roots of this plant is the richest. They are followed by leaves and stems. Capsules and flowers include also other components like coumarines and saponines.

Antimicrobial activity: The inhibition zones of different stains are measured. Table- 2 shows that the diameters of inhibition zones obtained respectively for the plant extracts of El Harmel on the chosen stumps.

Through Table-2, it is noted that $S$. aureus is strongly sensitive to ethanol extract of $P$. harmala $\mathrm{L}$ seeds with an inhibition zone of $19 \mathrm{~mm}$. This bacterium is resistant to aqueous and hexanic extract. E. coli is moderately sensitive to ethanol extract of $P$. harmala $\mathrm{L}$ with an inhibition zone of $15.21 \mathrm{~mm}$. It resists to aqueous and hexanic extract. $P$. aerogenosa is weakly sensitive to ethanolic extract of $P$. harmala $\mathrm{L}$ seeds with an inhibition zone of $10.54 \mathrm{~mm}$. It resists to aqueous and hexanic extract. So, B. subtilis is moderately sensible to the ethanol extract of $P$. harmala $\mathrm{L} 12.60 \mathrm{~mm}$. It is weakly sensitive to aqueous extract and resistant to hexanic extract. Whereas $K$. ornithinolytica is moderately sensitive to ethanol extract with an inhibition zone of $15.10 \mathrm{~mm}$. This bacterium is weakly sensitive to hexanic extract with an inhibition zone of 10.45 $\mathrm{mm}$ and it is also resistant to aqueous extract. But $K$. pneumonia is weakly sensitive to ethanol and hexanic extract with an inhibition zone of 12.75 and $10.9 \mathrm{~mm}$ respectively. This microorganism is resistant to aqueous extract. E. faecium is moderately sensitive to ethanol extract with an inhibition zone of $13.43 \mathrm{~mm}$ and weakly sensitive to hexanic extract, that is to say an inhibition zone of $11.71 \mathrm{~mm}$. It is resistant to aqueous extract. Finally, S. Faecalis is moderately sensitive to ethanol extract with an inhibition zone of $15.68 \mathrm{~mm}$ and weakly sensitive to hexanic and aqueous extract with an inhibition zone of $11.78 \mathrm{~mm}$ and $12.08 \mathrm{~mm}$, respectively.

For the yeasts and moulds, it is noted that $A$. niger and Penicilin $s p$. are resistant to three plant extracts of $P$. harmala L seeds which are ethanol extract, hexanic extract and aqueous extract. The F. oxysporum is moderately sensitive to ethanolic extract with an inhibition zone of $12.80 \mathrm{~mm}$. It is weakly resistant to aqueous extract, that is to say an inhibition zone of $10.49 \mathrm{~mm}$. This mushroom is resistant to hexanic extract. Whereas $C$. albicans is meoderately sensitive to ethanol extract with an inhibition zone of $14.31 \mathrm{~mm}$ and weakly 


\begin{tabular}{|c|c|c|c|c|c|c|c|c|c|c|}
\hline \multicolumn{11}{|c|}{$\begin{array}{c}\text { TABLE-2 } \\
\text { DIAMETERS OF INHIBITION ZONES (mm) OF } P . \text { harmala }\end{array}$} \\
\hline & & \multicolumn{3}{|c|}{ Aqueous extract } & \multicolumn{3}{|c|}{ Ethanolic extract } & \multicolumn{3}{|c|}{ Hexanic extract } \\
\hline \multirow{9}{*}{ 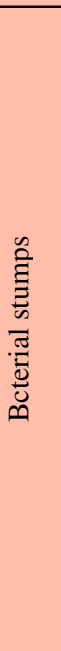 } & & $\begin{array}{l}\varnothing / \text { test } 1 \\
\text { and } 2\end{array}$ & $\begin{array}{l}\mathrm{M} \emptyset \\
(\mathrm{mm})\end{array}$ & $\mathrm{W}$ & $\begin{array}{c}\varnothing / \text { test } \\
1 \text { and } 2\end{array}$ & $\begin{array}{l}\mathrm{M} \varnothing \\
(\mathrm{mm})\end{array}$ & $\mathrm{W}$ & $\begin{array}{l}\varnothing / \text { test } 1 \\
\text { and } 2\end{array}$ & $\begin{array}{l}\mathrm{M} \emptyset \\
(\mathrm{mm})\end{array}$ & $\mathrm{W}$ \\
\hline & E. coli & $\begin{array}{l}9.00 \\
9.01\end{array}$ & 9.00 & 9.00 & $\begin{array}{l}14.31 \\
16.11\end{array}$ & 15.21 & 10.67 & $\begin{array}{c}10.07 \\
9.43\end{array}$ & 9.5 & 9.00 \\
\hline & S. aureus & $\begin{array}{l}9.00 \\
9.13\end{array}$ & 9.06 & 9.00 & $\begin{array}{l}18.35 \\
20.00\end{array}$ & 19.17 & 9.00 & $\begin{array}{c}10.00 \\
9.68\end{array}$ & 9.84 & 9.00 \\
\hline & P. aerugenosa & $\begin{array}{l}9.00 \\
9.00\end{array}$ & 9.00 & 9.00 & $\begin{array}{l}11.00 \\
10,08\end{array}$ & 10.54 & 9.00 & $\begin{array}{l}9.32 \\
9.62\end{array}$ & 9.47 & 9.00 \\
\hline & B. subtilis & $\begin{array}{l}10.14 \\
10.09\end{array}$ & 10.11 & 9.00 & $\begin{array}{l}13.11 \\
12.10\end{array}$ & 12.60 & 10.03 & $\begin{array}{l}9.29 \\
9.12\end{array}$ & 9.20 & 9.00 \\
\hline & K. ornithinolytica & $\begin{array}{l}9.02 \\
9.00\end{array}$ & 9.01 & 9.03 & $\begin{array}{l}13.05 \\
17.16\end{array}$ & 15.10 & 9.00 & $\begin{array}{c}11.00 \\
9.1\end{array}$ & 10.45 & 9.00 \\
\hline & K. pneumoniae & $\begin{array}{l}9.00 \\
9.00\end{array}$ & 9.00 & 9.07 & $\begin{array}{l}13.17 \\
12.33\end{array}$ & 12.75 & 9.00 & $\begin{array}{c}12.00 \\
9.80\end{array}$ & 10.90 & 9.00 \\
\hline & E. faecium $D$ & $\begin{array}{r}9.00 \\
9.04\end{array}$ & 9.02 & 9.10 & $\begin{array}{l}16.00 \\
10.87\end{array}$ & 13.43 & 9.03 & $\begin{array}{l}10.36 \\
13.07\end{array}$ & 11.71 & 9.00 \\
\hline & Strp. Faecalis & $\begin{array}{l}12.10 \\
12.06 \\
\end{array}$ & 12.08 & 9.00 & $\begin{array}{l}17.06 \\
14.31 \\
\end{array}$ & 15.68 & 10.00 & $\begin{array}{l}12.00 \\
11.56 \\
\end{array}$ & 11.78 & 9.00 \\
\hline \multirow{5}{*}{ 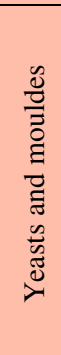 } & A.niger & $\begin{array}{l}9.00 \\
9.00\end{array}$ & 9.00 & 9.00 & $\begin{array}{l}9.00 \\
9.00\end{array}$ & 9.00 & 9.00 & $\begin{array}{l}9.00 \\
9.00\end{array}$ & 9.00 & 9.00 \\
\hline & F. oxysporum & $\begin{array}{l}10.87 \\
10.12\end{array}$ & 10.49 & 9.00 & $\begin{array}{l}13.08 \\
12.53\end{array}$ & 12.80 & 9.00 & $\begin{array}{l}11.07 \\
10.91\end{array}$ & 10.99 & 9.00 \\
\hline & Penicillium $s p$ & $\begin{array}{l}9.00 \\
9.00\end{array}$ & 9.00 & 9.00 & $\begin{array}{l}9.00 \\
9.00\end{array}$ & 9.00 & 9.00 & $\begin{array}{l}9.00 \\
9.00\end{array}$ & 9.00 & 9.00 \\
\hline & C. albicans & $\begin{array}{c}10.16 \\
9.78\end{array}$ & 9.97 & 10.00 & $\begin{array}{l}13.56 \\
15.07\end{array}$ & 14.31 & 10.65 & $\begin{array}{l}12.16 \\
11.26\end{array}$ & 11.71 & 9.00 \\
\hline & S. cerievisea & $\begin{array}{l}9.00 \\
9.07\end{array}$ & 9.03 & 9.00 & $\begin{array}{l}17.46 \\
16.31\end{array}$ & 16.88 & 9.00 & $\begin{array}{l}9.07 \\
9.15\end{array}$ & 9.11 & 9.00 \\
\hline
\end{tabular}

W: witness; Ø: diameter

sensitive to hexanic extract with an inhibition zone of 11.71 $\mathrm{mm}$. It is resistant to aqueous extract. But $S$. cerievisea is sensitive to ethanol extract with an inhibition zone of 16.88 $\mathrm{mm}$. It is resistant to hexanic and aqueous extracts.

From the results of antimicrobial activity, it is noticed that plant extract of $P$. harmala $\mathrm{L}$ seeds have inhibitory actions on all bacterial stains but with different degrees. The diameter of inhibition zone varies from a stump to another. Antimicrobial activity of plant extracts depends on two essential parameters. The first parameter is the nature and the composition of the extract. Whereas the second parameter is the genotype of microbial stump.

Antimicrobial activity of a substance is due to the presence of some molecules endowed with this power. In fact, the seeds of $P$. harmala L. are rich of some alkaloids like harmaline, harmine and harman which possess antimicrobial properties ${ }^{19}$. These alkaloids also showed antifungal activity ${ }^{20}$.

According to the results of the present study, plant extracts of Harmel seeds possess antimicrobial activity and the most sensitive stain is $S$. aureus with a diameter of $19.17 \mathrm{~mm}$ of the inhibitory zone for the ethanol extract. Whereas the most resistant stain is $P$. aerogenosa with a diameter of $10.54 \mathrm{~mm}$ of the inhibition zone for the ethanol extract.

The results of the present work are similar to the works of Pibiri $^{21}$. He has reported that $P$. aeroginosa is well known to be very resistant to many antimicrobial agents and antibiotics in general. This is probably due to the capacity of bacteria to form a bio-film or a polysaccharide barrier. This barrier is a complex organization composed of different strata connected from the inside to the external membrane where the bacteria are found in a specific physiological state to their situation. So, all the bacterial population is not simultaneously and identically exposed to the product. It is established that the treatment of such bacteria require considerable concentrations of antimicrobial agents.

In addition, according to the obtained results, Grampositive bacteria present different effects. It is noticed that $S$. aureus is more sensitive to plant extracts comparing to B. subtilis which turned out to be slightly sensitive to these products. According to Balentine et al. ${ }^{22}$, the hypersensitivity of $S$. aureus can be explained by the probability of the sensitivity of Gram-positive bacteria to the external environmental changes such as the temperature, the $\mathrm{pH}$ and the natural extracts. This sensitivity is probably due to the absence of external membrane in bacteria.

However, Cosentino et al. ${ }^{23}$, Debillerbeck ${ }^{24}$, Marino et $a l .{ }^{25}$, Yadava and Verma ${ }^{26}$ indicate that Gram-negative bacteria are more sensitive than Gram-positive bacteria. Chao et al. ${ }^{27}$ explain this phenomenon by the fact that Gram-negative bacteria are endowed with a layer of peptidoglycans wedged between plasma membrane and an external stratum made up of lipopolysaccharids and proteins. These proteins play a role of a barrier against the plant extracts.

El Gayyar et $a l .{ }^{28}$ and Delaquis et al..$^{29}$ disagree with this report. They confirm that each bacterium Gram-positive is different from a bacterium Gram-negative in its structure and its function. 
The results of the antifungal activity reveal the inefficiency of all the extracts against the majority tested stains which could be due to a contamination. Consequently, the results show inhibition zones of ethanol extracts of El Harmel seeds against $C$. albicans, of $S$. cerievisea and of $F$. oxysporum. These microorganisms have an action which is moderately sensitive ${ }^{30}$.

According to $\mathrm{Gomah}^{31}$, when the alkaloids of P. harmala L. seeds are individually examined on $B$. subtilis and on $C$. albicans, these pathogens agents are more sensitive to harmin. Whereas Harman is more active against E.coli and A. niger. Harmalin is more efficient against $C$. albicans. Whereas harmalol shows a moderate activity. A combination of harman and harmine is the most efficient against $E$. coli, but a mixture of Harman and harmaline gives good results against $C$. albicans. Delaquis et l. $^{29}$ indicate that Berberis aetnensis methanolic root extract showed good activity against C. albicans, $C$. krusei and $C$. tropicalis, meanwhile, the isolated isoquinoline alkaloid berberine generally showed weaker activity.

Reza et $a l .^{32}$ notes that there are many reports in literature showing a variety of pharmacological activities for the P. harmala L.

In addition to the antimicrobial effect and fungicidal effect of tested extracts, they possess a nematicidal activity. According to El Allagui et al. ${ }^{18}$, Harmal has a nematicidal effect on mortality, the opening and the development of Meloidogyne. This action is attributed essentially to the richness of this plant in alkaloids and in combined quinones.

What emerged from this study is the efficiency of different extracts of Harmel seeds. The antimicrobial activity is in relation with the nature of the solvent of extraction whose ethanol extract possesses a very powerful antimicrobial activity. It is followed by hexanic and aqueous extracts through the majority of tested stumps. This action is attributed to the richness of seeds in alkaloids like harmaline and harmine. These later are slightly soluble in water, ethanol and ether ${ }^{33}$. Whereas harmane is highly soluble in methanol, ethanol, acetone, chloroform and ether ${ }^{34}$.

The efficiency of harmel extracts is explained by the degree of solubility in water, hexane and ethanol of alkaloids contained in seeds. In this work, the antimicrobial activity of different extracts of the Harmel showed an optimal activity with the ethanol extract. This results is not consistent with that of ${ }^{35-36}$. Gupta et al. ${ }^{35}$ note that the chloramphenicol extract of fruit of Tribulus terrestris (Zygophyllaceae) is more reliable than the ethanol extract. Basaran et al. ${ }^{36}$ provides data on the antifungal properties of the methanolic extract. Since harmaline and harmine are not very soluble in water and ethanol, it is mentioned that the efficiency of ethanol extract on tested stumps is due to harman alkaloids.

\section{Conclusion}

This study is conducted to increase the value of a local species which is $P$. harmala $\mathrm{L}$ by the evaluation of the antimicrobial effects of plant extracts of EL Harmel seeds obtained after extraction using solvent. In other respects, preliminary tests are done on the powder of Harmel seeds in order to show the presence of some secondary metabolites via different reactions of colouration done with the very used reactives in searching and identifying these metabolites. The conducted phytochemical study shows that $P$. harmala $\mathrm{L}$ is characterized by its richness in alkaloids, in saponosides and in coumarines. After determining the operatory conditions of extraction at the level of the laboratory, we proceed to the extraction. For this purpose, three solvents were used; it is about hexane, ethanol and water for the solvent part. Finally, we are attached to study the antimicrobial and antifungal activity of diverse extracts against different germs. The evaluation of the antimicrobial effect of the plant extracts of $P$. harmala $\mathrm{L}$ seeds has permitted to affirm that it has an inhibitor power against some microorganism tested independently from their Gram and their morphology. S. aureus and E. coli are very sensitive to ethanol extract. P. aerugenosa and Penicillium sp are resistant to that extract. The other microorganisms are moderately sensitive. The antimicrobial activity study of different extracts of Harmel has shown an optimal activity with the extract of ethanol.

It concluded from this work that $P$. harmala $\mathrm{L}$ is a medicinal plant which has many substances with medical interest. Among these substances, we have alkaloids found in the seed in interesting quantity and quality. The present work shows the interest of $P$. harmala $\mathrm{L}$ in traditional medicine under different using forms.

\section{REFERENCES}

1. J.-C. Roland, Des plantes et des hommes, Vinbert Press, Paris, p. 163 (2002).

2. A. Lhuillier, Ph.D. Thesis, Contribution à l'étude phytochimique de quatre plantes malgoches: Agauria salicifolia, Hook.f ex Olivier Agauria polyphylla, Baker (Ericaceae), Tambourissa trichophylla Baker (Monimiaceae) et Ombelia concinna Baker (Myrinaceae), Toulouse, France, p. 98 (2007).

3. P. Delaveau, Histoire et renouveau des plantes médicinales, Albin Michel Press, Paris, p. 5 (1982)

4. O. Catier and D. Roux, Botanique pharmacognosie phytothérapie, Wolters Kluwer Collection Porphyre Press, France, pp. 89-90 (2007).

5. K. Sekkoum, A. Cheriti and S. Taleb, Asian J. Chem., 22, 2891 (2010).

6. A. Hallimi, Les plantes médicinales en Algérie, Berti Press Algérie, p. 42 (2004).

7. Q.A. El-Dwairi, Asian J. Chem., 19, 3887 (2007).

8. P. Iserin, Encyclopédie des plantes médicinales, Larousse Press, France, p. 335 (2001).

9. I.E. Leger, Debaene Press, France, vol. 2, pp. 360-860 (1989).

10. G. Sacchetti, S. Maietti, M. Muzzoli, M. Scaglianti, S. Manfredini, M. Radice and R. Bruni, Food Chem., 91, 621 (2005).

11. O.Y. Celiktas, E.E.H. Kocabas, E. Bedir, F.V. Sukan, T. Ozek and K.H.C. Baser, J. Food Chemistry, 100, 553 (2007).

12. J.L. Fauchere and J.L. Avril Albin, Ellipses Press, Paris, p. 365 (2002).

13. C. Munir, M.I. Zaidi, A. Nasir, U. Atta and N. Ahmad, Fitoterapia, 66, 73 (1995).

14. M. Kartal, M.L. Altun and S. Kurucu, J. Pharm. Biomed. Anal., 31, 263 (2003).

15. M.K. Han, S.I. Kim and Y.J. Ahn, J. Stored Prod. Res., 42, 15 (2006).

16. L.M. Idrissi Hassani and M. El Hadek, Acta Bot. Gallica, 146, 353 (1999).

17. L. Claude, Contribution à l'étude de Peganum harmala L., Thèse de pharmacie, France, p. 335 (1967).

18. N. El Allagui, M. Bourijate and S. Tahrouch, Congrès International de Biochimie, Aghadir, pp. 360-357 (2006).

19. A. R. Shahverdi, Monsef-Esfahani H R, Nickavar B, Bitarafan L, Khodaee S, Khoshakhlagh, Z. Naturforsch., 60 C, 707 (2005).

20. M. R. Boukef, Les plantes dans la médicine traditionnelle tunisienne. A.C.C.T. Press, Paris, p. 350 (1986).

21. M.C. Pibiri, Assainissement microbiologique de l'air et du système de ventilation au moyen d'huile essentielle, Thèse de Doctorat, Ecole polytechnique fédérale, Lausanne, p. 177 (2006).

22. C.W. Balentine, P.G. Crandall, C.A. O'bryan, D.Q. Duong and F.W. Pohlman, Meat Sci., 73, 413 (2006). 
23. S. Cosentino, C.I.G. Tuberoso, B. Pisano, M. Satta, V. Mascia, E. Arzedi and F. Palmas, Lett. Appl. Microbiol., 29, 130 (1999).

24. G. Debillerbeck, Activité antifongique de l'huile essentielle de Cymbopogon nardus sur Aspergillus niger. Evaluation d'un bioréacteur pour l'Etude de l'effet inhibiteur des substances volatiles en phase vapeur, Thèse de doctorat, Faculté des sciences pharmaceutiques. Institut national polytechnique Toulouse, p. 236 (2000).

25. M. Marino, C. Bersani and G. Comi, J. Food Prot., 62, 1023 (1999).

26. R.N. Yadava and V. Verma, Asian J. Chem., 15, 842 (2003).

27. S.C. Chao, D.G. Young and C.J. Oberg, J. Essent. Oils Res., 12, 639 (2000)

28. M. El Gayyar, F.A. Graughon, D.A. Golden and J.R. Mount, J. Food Prot., 64, 1019 (2001).

29. P.J. Delaquis, K. Tanish, B. Girard and G. Mazza, Int. J. Food Microbiol., 74, 101 (2002)
30. L. Iauk, R. Costanzo, F. Caccamo, A. Rapisarda, R. Musumeci, I. Milazzo and G. Blandino, Fitoterapia, 78, 159 (2007).

31. G. Nenaah, Fitoterapia, 81, 779 (2010).

32. H.R. Monsef, A. Ghobadi, M. Iranshahi and M. Abdollahi, J. Pharm. Pharmaceut. Sci., 7, 65 (2004).

33. M. Mahmoudian, H. Jalipour and P. Salehian, Iran. J. Pharmacol. Therap., 1, 1 (2002).

34. J.S. Glasby, Encyclopedia of the Alkaloids, Plenum Press, France, pp. 58-61 (1978).

35. S.K. Gupta, P.K. Sharma and S.H. Ansari, Asian J. Chem., 17, 1355 (2005).

36. D. Basaran, H. Nurcihan, S. G. Beyza and G.F. Gucin, Asian J.Chem., 22, 6321 (2010). 